\title{
Article \\ Aluminium, Iron and Silicon Subcellular Redistribution in Wheat Induced by Manganese Toxicity
}

\author{
Jorge M. S. Faria ${ }^{1,2, *(\mathbb{D} \text {, Dora Martins Teixeira }}{ }^{3,4}$, Ana Paula Pinto ${ }^{2,4}$, Isabel Brito ${ }^{2,4}$, Pedro Barrulas ${ }^{3}$ D \\ and Mário Carvalho 2,4 \\ 1 INIAV, I.P., National Institute for Agrarian and Veterinarian Research, Quinta do Marquês, \\ 2780-159 Oeiras, Portugal \\ 2 MED, Mediterranean Institute for Agriculture, Environment and Development, \\ Institute for Advanced Studies and Research, Évora University, Pólo da Mitra, Ap. 94, \\ 7006-554 Évora, Portugal; app@uevora.pt (A.P.P.); ibrito@uevora.pt (I.B.); mjc@uevora.pt (M.C.) \\ 3 HERCULES Laboratory, Évora University, Largo Marquês de Marialva 8, 7000-809 Évora, Portugal; \\ dmt@uevora.pt (D.M.T.); pbarrulas@uevora.pt (P.B.) \\ 4 Science and Technology School, Évora University, Rua Romão Ramalho 59, 7000-671 Évora, Portugal \\ * Correspondence: fariajms@gmail.com
}

Citation: Faria, J.M.S.; Teixeira, D.M.; Pinto, A.P.; Brito, I.; Barrulas, P.; Carvalho, M. Aluminium, Iron and Silicon Subcellular Redistribution in Wheat Induced by Manganese Toxicity. Appl. Sci. 2021, 11, 8745. https://doi.org/10.3390/app11188745

Academic Editor: Rafael López Núñez

Received: 14 August 2021

Accepted: 17 September 2021

Published: 19 September 2021

Publisher's Note: MDPI stays neutral with regard to jurisdictional claims in published maps and institutional affiliations.

Copyright: (C) 2021 by the authors. Licensee MDPI, Basel, Switzerland. This article is an open access article distributed under the terms and conditions of the Creative Commons Attribution (CC BY) license (https:// creativecommons.org/licenses/by/ $4.0 /)$.

\begin{abstract}
Acidic soils can promote the bioavailability of $\mathrm{Al}, \mathrm{Mn}$, and Fe to toxic levels, reducing crop growth and productivity. Symptoms of metal excess/deficit are dependent on the chemical composition of the soil solution and of plant tissues. In the present study, the concentration and subcellular distribution of $\mathrm{Al}, \mathrm{Mn}, \mathrm{Fe}$, and $\mathrm{Si}$ (known to alleviate metal stress) were quantified through inductively coupled plasma mass spectrometry (ICP-MS) in roots and shoots of wheat grown in acidic soils with rising levels of $\mathrm{Mn}$. In control acidic soil, wheat showed high concentrations of $\mathrm{Al}, \mathrm{Mn}$, and Fe. After Mn supplementation, bioavailable $\mathrm{Al}, \mathrm{Fe}$, and $\mathrm{Si}$ levels increased in the soil solution, but plant uptake ratio decreased. Root Mn levels increased, while those of $\mathrm{Al}, \mathrm{Fe}$, and $\mathrm{Si}$ decreased. Although elements were increasingly translocated to the shoot, root $\mathrm{Al}$ and Fe concentrations were 10-fold higher than those in the shoot. At the highest Mn concentration supplied, Al, Fe, and Si proportions increased in the organelles, while Mn proportion increased in the vacuole. High bioavailable Mn levels disrupt metal homeostasis in wheat grown in acidic soils, influencing element subcellular distribution. Symptoms of metal toxicity result from interactions between several elements, and therefore a comprehensive chemical analysis of soil solution and plant tissues contributes to a more accurate understanding of their uptake dynamics and their agronomic implications.
\end{abstract}

Keywords: aluminium; apoplast; ICP-MS; iron; manganese toxicity; silicon; soil acidity

\section{Introduction}

Soil acidity is a major concern in worldwide agricultural systems, influencing crop production in 30-40\% of agricultural lands and dominating up to $60 \%$ of potentially arable lands, which hinders the establishment of new agricultural soils in tropic and subtropic regions [1,2]. Soil acidity promotes the release of $\mathrm{Al}, \mathrm{Fe}$, and $\mathrm{Mn}$ from their soil-bound forms into bioavailable $\mathrm{Al}^{3+}, \mathrm{Fe}^{2+}$, and $\mathrm{Mn}^{2+}$. The intensity of this phenomenon is influenced by $\mathrm{pH}$ and redox potential but also by the temperature and moisture of the soil, generally leading to co-occurring ion toxicities [3,4]. The increase in soil $\mathrm{H}^{+}$and bioavailable Al, $\mathrm{Fe}$, and Mn levels leads to a decline in soil fertility by promoting deficiencies in plant essential nutrients, namely, magnesium $(\mathrm{Mg})$, calcium $(\mathrm{Ca})$, and potassium $(\mathrm{K})$, and a decrease in the solubility of phosphorus (P) and molybdenum (Mo) [5,6]. Furthermore, the excessive agricultural use of ammonium-based fertilizers and natural waterlogging events can decrease soil $\mathrm{pH}$ and increase the detrimental effects of soil acidity on plant growth $[7,8]$. 
In plants growing on acidic soils, a clear diagnosis of metal toxicity is particularly challenging, given that different elements can show similar symptoms in above-ground plant parts, different symptoms can be observed in different families or groups of plants, and different degrees of co-occurrent toxicities and associated nutrient deficiencies can be active at any given site [3]. The simultaneous elemental analysis of soil, plant tissues, and respective subcellular compartments can provide important information for assessing not only element toxicity but also mechanisms of plant tolerance.

Wheat (Triticum aestivum L.) is one of the most widely cultivated cereal crops worldwide, and its demand is projected to increase as much as $60 \%$ by 2050 . Wheat productivity can be heavily impaired by soil acidity, namely, by the associated effects of high levels of bioavailable $\mathrm{Al}, \mathrm{Fe}$, and $\mathrm{Mn}$ in the soil [9]. For Al toxicity, symptoms are mainly detected below ground through the impairment of root growth, at the meristematic regions, and a reduction in cell elongation and root hair development. Excess of $\mathrm{Al}$ induces cell wall modifications, interruption of signalling pathways, disruption and depolarisation of the plasma membrane, modified transport processes, and Al binding to the DNA [10]. Secondary symptoms can be detected in the aerial parts after excess $\mathrm{Al}$ impairs root nutrient acquisition and water uptake [11,12]. Plants can counter Al toxicity by preventing its uptake at the root apex or by chemical chelation (with organic acids and other compounds) and detoxifying intracellular $\mathrm{Al}$ in excess $[2,13]$. For example, in some wheat cultivars, exclusion of Al-malate complexes appears to promote tolerance to $\mathrm{Al}$ toxicity [14].

Iron toxicity is mainly diagnosed in crops growing in flooded soils, and thus a large amount of research has focused on rice. Toxicity in rice is characterised by a phenomenon called "bronzing", the spread of scattered reddish-brown spots in older leaves that progresses to cover the entire organ [15]. This process is caused by the accumulation of oxidised polyphenols and the irreversible damage of cell structural components, induced by an elevated production of radicals. Tolerance to Fe toxicity is based on either its exclusion from the root (strategy I), its subcellular compartmentalisation and exclusion from the symplast (strategy II), or through enzymatic detoxification (strategy III) [15]. In wheat, Fe toxicity is not extensively reported, and is mainly described for flooded soils, where it can co-occur with Mn toxicity, in years of heavy rainfall. The impairment of wheat growth and a yellowing of older leaves are the most commonly reported symptoms [16,17].

Manganese and $\mathrm{Al}$ toxicities are the main constraints to plant productivity on acidic soils. In wheat, excessive levels of $\mathrm{Mn}$ are generally translocated to the aerial parts. A decline on growth and productivity is associated with stunting, chlorosis, necrotic spots, white flecking, purpling, and leaf tip burn, that progresses from older to younger leaves $[18,19]$. Similarly to $\mathrm{Al}, \mathrm{Mn}$ toxicity can alter the uptake of other essential nutrients, since it generally competes for shared transporter proteins [20-22]. For instance, Mn toxicity symptoms can many times be confused with light Fe deficiency [23].

To counteract soil acidity and derived ion toxicities in agricultural soils, pulverised calcitic lime (Ca carbonates and oxides) or dolomitic lime (Ca and $\mathrm{Mg}$ carbonates) are commonly used. However these soil correctives have shown significant drawbacks, namely, by greatly increasing farming costs; by being seldomly used in the required amounts; and, depending on soil characteristics, by being countered by the soil's strong buffering capacity [24]. Besides $\mathrm{Mg}$ and $\mathrm{Ca}$ (used for soil correction as dolomitic lime), $\mathrm{Si}$ is also known to counter Mn and Al toxicities and, depending on plant species and/or variety, can influence mechanisms of detoxification and compartmentation, either by preventing internal metal excess or by influencing internal metal distribution [23,25-27].

In the acidic Cambic soils of south-eastern Portugal, agricultural productivity is heavily affected by Mn toxicity and low fertility [28]. Defining strategies to diagnose Mn toxicity and improve wheat production has been an on-going research effort [29-31]. In wheat growing in an acidic Cambic soils, the occurrence of Mn toxicity symptoms depends heavily on maintaining shoot $\mathrm{Mg} / \mathrm{Mn}$ ratios above 20 [32-35]. In fact, wheat can mobilise various root and shoot nutrients to counter Mn toxicity. Magnesium, Ca, Mn, and P can be redistributed intracellularly in wheat roots and shoots as a response to toxic levels of 
bioavailable Mn [28]. While Ca accumulates in the root apoplast, Mn, along with P and $\mathrm{Mg}$, are redirected to the shoot vacuole as a detoxification strategy.

The present study characterises the contents of $\mathrm{Mn}, \mathrm{Al}, \mathrm{Fe}$ (commonly promoted in acidic soils), and $\mathrm{Si}$ (that has shown beneficial effects under Mn toxicity) in the soil solution and wheat roots, shoots, and their respective subcellular fractions (fractions enriched in cell wall debris, organelles, or vacuole contents). This work assessed the effect of rising levels of soil bioavailable $\mathrm{Mn}$ on the uptake and subcellular redistribution of these elements in wheat tissues. Screening the mechanisms involved in wheat detoxification allows for the establishment of more precise agricultural practices that enhance natural detoxification processes.

\section{Materials and Methods}

\subsection{Characterisation of the Soil and Soil Solution}

The acidic soil used was a granitic Eutric Cambisol collected from the top $20 \mathrm{~cm}$ of the headland for a long-term natural pasture at Mitra farm, Évora University, Alentejo, Portugal $\left(38^{\circ} 32^{\prime} \mathrm{N} ; 08^{\circ} 00^{\prime} \mathrm{W}\right)$. The air-dried and sieved $(2 \mathrm{~mm})$ soil with a $\mathrm{pH}$ of 5.6 (soil/water = 1:2.5 $(w / v)$ ) contained $23 \mathrm{mg} \mathrm{P} / \mathrm{kg}$ (Egner-Rhiem), $0.4 \mathrm{mg} \mathrm{N}-\mathrm{NO}_{3} / \mathrm{kg}, 22.6 \mathrm{mg}$ $\mathrm{Mn} / \mathrm{kg}$ (DTPA-diethylenetriaminepentaacetic acid), $9 \mathrm{~g} \mathrm{SOM}$ (soil organic matter-chromic acid wet oxidation) $/ \mathrm{kg}$, a cation exchange capacity (CEC) of 3.0 centimoles of charge per kilogram $(\mathrm{cmol}(+) / \mathrm{kg})$, and a base saturation of $37 \%[28,29,36]$.

Increased levels of bioavailable toxic Mn were obtained after supplementation of 0 , 45.2 , or $90.4 \mathrm{mg} \mathrm{MnCl}_{2}$ per kg of soil, which corresponded to zero, two-, and fourfold the Mn levels for the acidic soil, respectively, and were left to rest for a week [28].

The soil solution was extracted according to [33] with the modifications described in [28]. Briefly, the aqueous solution was isolated from around $40 \mathrm{~g}$ of acidic soil surrounding the wheat root system through centrifugation at $2500 \times \mathrm{g}$, for $60 \mathrm{~min}$, at $4{ }^{\circ} \mathrm{C}$, in $50 \mathrm{~mL}$ tubes fitted with a $0.45 \mu \mathrm{m}$ polyethersulfone filter. Volume of the extracted soil solution was recorded, and the soil solution was kept at $-20^{\circ} \mathrm{C}$.

\subsection{Experimental Setup}

Four Triticum aestivum L. seedlings (cv. Ardila) were planted in dark plastic pots (8 L) containing the $\mathrm{MnCl}_{2}$-supplemented acidic soil. Pots were maintained fully randomised in a greenhouse and weighed every day. Soil was kept from dehydration with deionised water to around $70 \%$ of maximum water holding capacity. Minimum and maximum air temperatures were recorded daily, and temperature control of the greenhouse was set to a maximum of $30^{\circ} \mathrm{C}$. Wheat plants were collected after three weeks of growth, and the roots were washed with ultrapure water. Roots and shoots were separately flash frozen in liquid $\mathrm{N}_{2}$ and kept at $-80^{\circ} \mathrm{C}$.

\subsection{Wheat Subcellular Element Distribution}

Element subcellular distribution was assessed for wheat shoots and roots according to [29]. Briefly, finely grounded frozen roots and shoots were obtained using a melamine mortar and pestle and liquid nitrogen. Samples were then mixed in a cold $50 \mathrm{mM}$ Tris$\mathrm{HCl}(\mathrm{pH} 7.5)$ aqueous solution, at $4{ }^{\circ} \mathrm{C}$, containing sucrose $(250 \mathrm{mM})$ and dithioerythritol $(1.0 \mathrm{mM})$, in a ratio of $200 \mathrm{mg}$ of sample (fresh weight, F.W.) $/ 5 \mathrm{~mL}$ of solution. Following this, differential centrifugation was performed to isolate the (1) cell wall fraction (CWF) by centrifuging the homogenate at $2500 \times g$ for $15 \mathrm{~min}$ in order to pellet cell walls, cellular debris, and metal granules; (2) organelle fraction (OF) by centrifuging the previous supernatant at $100,000 \times g$ for $60 \mathrm{~min}$ in order to pellet cellular organelles, e.g., mitochondria and chloroplasts; and (3) vacuole fraction (VF), mainly comprised of vacuole contents and soluble components of the cytosol, contained in the supernatant of the previous centrifugation. All centrifugation steps were performed at $4{ }^{\circ} \mathrm{C}$, and the resulting fractions were maintained at $-80^{\circ} \mathrm{C}$. 


\subsection{Manganese, Aluminium, Iron, and Silicon Analysis}

Inductively coupled plasma mass spectrometry (ICP-MS) was performed to quantify sample $\mathrm{Mn}, \mathrm{Al}, \mathrm{Fe}$, and $\mathrm{Si}$ levels. Preparation of digested samples and quantitative analysis were performed according to [28].

\subsubsection{Acid Digestion of Wheat Tissues}

Ground roots or shoots $(50 \mathrm{mg})$ and respective fractions were freeze dried in a Telstar LyoQuest apparatus for three days. Freeze dried samples were added to $2 \mathrm{~mL}$ of $\mathrm{HNO}_{3}$ (Suprapur, 67-69\%, Fisher Chemicals, Hampton, NH, USA) and maintained in closed Teflon beakers at room temperature for $12 \mathrm{~h}$. These solutions were then heated $\left(<120^{\circ} \mathrm{C}\right)$ for $24 \mathrm{~h}$ and $0.5 \mathrm{~mL}$ of $\mathrm{H}_{2} \mathrm{O}_{2}$ (Suprapur, 30\%, Merck, KGaA, Darmstadt, Germany) were added to further digest the organic material at $80^{\circ} \mathrm{C}$. Fully digested samples were heated to $100{ }^{\circ} \mathrm{C}$ and the remaining solid residue was dissolved in $50 \mathrm{~mL}$ of a $2 \% \mathrm{HNO}_{3}$ aqueous solution for ICP-MS analysis. NIST SRM 1573a (tomato leaves) certified reference material and one digestion blank were simultaneously digested for method validation, namely, evaluation of accuracy and limits of detection for each element.

\subsubsection{Quantitative Element Analysis}

Elemental quantification was performed on an Agilent 8800 Triple Quadrupole ICPMS, equipped with a Micromist nebuliser. Agilent ICP-MS tuning solution, $2 \% \mathrm{HNO}_{3}$ containing $10 \mu \mathrm{g} / \mathrm{L}$ each of Ce, Co, Li, Tl, and Y (Agilent Technologies, Palo Alto, CA, USA), was used for instrument optimisation. External calibration was performed with the multi-element certificate standard solution ICP-MS-68B-A (100 mg/L) from High-Purity Standards (Charleston, SC, USA). Matrix effects and instrumental drifts were corrected on the basis of the internal standards ruthenium $(\mathrm{Ru})$, rhodium $(\mathrm{Rh})$, and iridium $(\mathrm{Ir})$. The collision/reaction cell was set to "no-gas mode" for the quantification of $\mathrm{Al}$ and $\mathrm{Mn}$, "O⿰冫一⿻上丨 mode" for the quantification of $\mathrm{Si}$, and "NH $\mathrm{N}_{3}$ mode" for the quantification of Fe. Plasma gas flow rate was $15 \mathrm{~mL} / \mathrm{min}$, and collision and reaction gas flow rates were $0.5 \mathrm{~mL} / \mathrm{min}$ for $\mathrm{O}_{2}$ and $1.5 \mathrm{~mL} / \mathrm{min}$ for $\mathrm{NH}_{3}$. Analyses were optimised at $1550 \mathrm{~W}$ forward power and $1.1 \mathrm{~L} / \mathrm{min}$ Ar carrier gas flow with no dilution or makeup gas. Sampling depth $(10 \mathrm{~mm})$ and lens parameters were optimised for highest signal and optimum peak shape while maintaining low oxides and doubly charged species. MS/MS scan type was used in all the operation modes.

\subsection{Data Analysis}

For each element, uptake dynamics were characterised by determining root or shoot bioconcentration factors (BCF, root or shoot element concentration/soil solution element concentration), the translocation factor (TF, shoot element concentration/root element concentration), and bioaccumulation coefficient (BAC, plant element concentration/soil solution element concentration), according to [37].

Statistical analysis was performed with SPSS version 26 statistics software. Statistical significance of data was determined with one-way ANOVA, using Tukey's post hoc test for means comparison at a 95\% significance level $(p<0.05)$. Shapiro-Wilk test and Browns-Forsythe test were used for the evaluation of normality and homoscedasticity, respectively. The presented results correspond to the average and standard error of four biological replicates.

\section{Results}

3.1. Manganese

Mn levels in the soil solution increased drastically after Mn supplementation (Table 1). 
Table 1. Concentration of Mn, Al, Fe, and Si ( $\mu$ g element/kg soil DW) in the soil solution extracted from the $\mathrm{MnCl}_{2}$ supplemented acidic soil, in the vicinity of roots of wheat grown for 3 weeks.

\begin{tabular}{|c|c|c|c|}
\hline \multirow{2}{*}{$\begin{array}{c}\text { Element } \\
\mu \mathrm{g} / \mathrm{kg}\end{array}$} & \multicolumn{3}{|c|}{$\mathrm{mg} \mathrm{MnCl}_{2} / \mathrm{kg}$ Soil DW } \\
\hline & 0.0 & 45.2 & 90.4 \\
\hline $\mathrm{Mn}$ & $642.0 \pm 5.6$ & $2247.4 \pm 13.8$ & $4152.8 \pm 46.9$ \\
\hline $\mathrm{Al}$ & $233.0 \pm 3.4$ & $264.8 \pm 2.4$ & $280.7 \pm 4.1$ \\
\hline $\mathrm{Fe}$ & $8.4 \pm 0.0$ & $8.7 \pm 0.1$ & $9.4 \pm 0.0$ \\
\hline $\mathrm{Si}$ & $768.7 \pm 9.1$ & $879.1 \pm 13.9$ & $996.8 \pm 13.6$ \\
\hline
\end{tabular}

Similarly, higher Mn levels were detected in wheat roots and shoots. Shoot Mn levels increased more pronouncedly than those of wheat roots, which led to increasing TF values (Figure 1a). After Mn supplementation, plant Mn uptake ratio was inhibited (decrease in $\mathrm{BAC})$, but root to shoot translocation was promoted (decrease in root BCF and increase in shoot BCF) (Figure 1b).

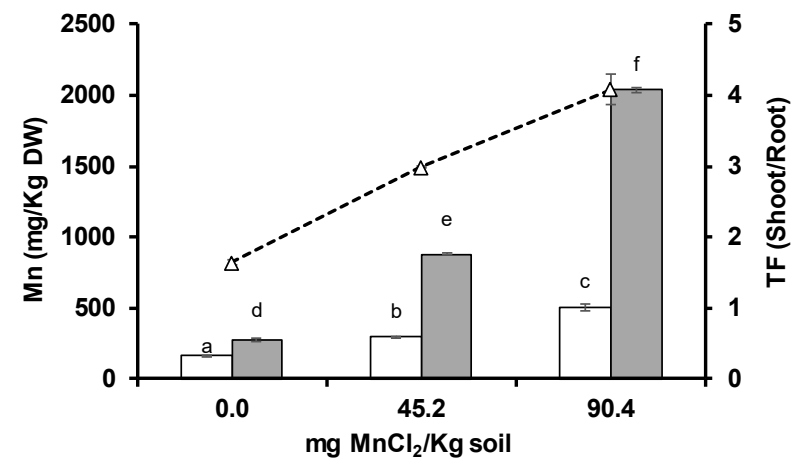

(a)

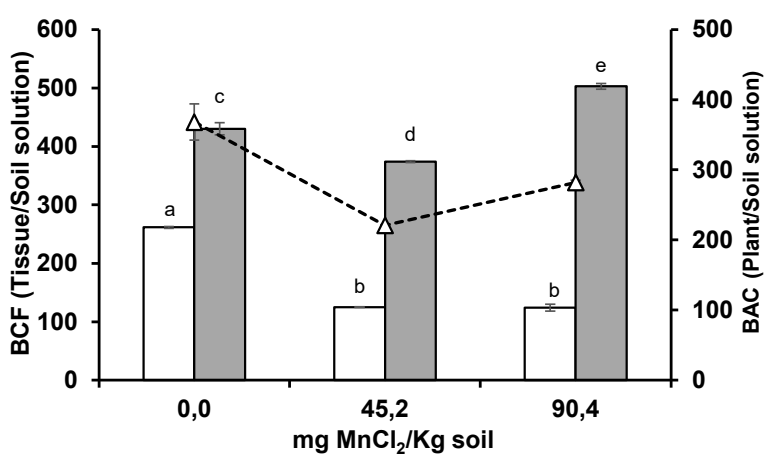

(b)

Figure 1. Concentration $((\mathbf{a})$, columns), translocation factor $(\mathrm{TF}$, triangles) $((\mathbf{a})$, line), bioconcentration factors (BCF) ((b), columns), and bioaccumulation coefficient (BAC, triangles) ((b), line) of $\mathrm{Mn}$ in roots (white columns) and shoots (grey columns) of wheat grown for 3 weeks in an acidic soil supplemented with $\mathrm{MnCl}_{2}$. Different letters indicate statistically significant differences $(p<0.05)$ on the basis of Tukey's test.

In wheat roots, the pattern of $\mathrm{Mn}$ subcellular distribution showed no major change (Figure 2a), while in the shoots, Mn proportion increased in the fraction containing vacuole contents (Figure $2 b$ ).

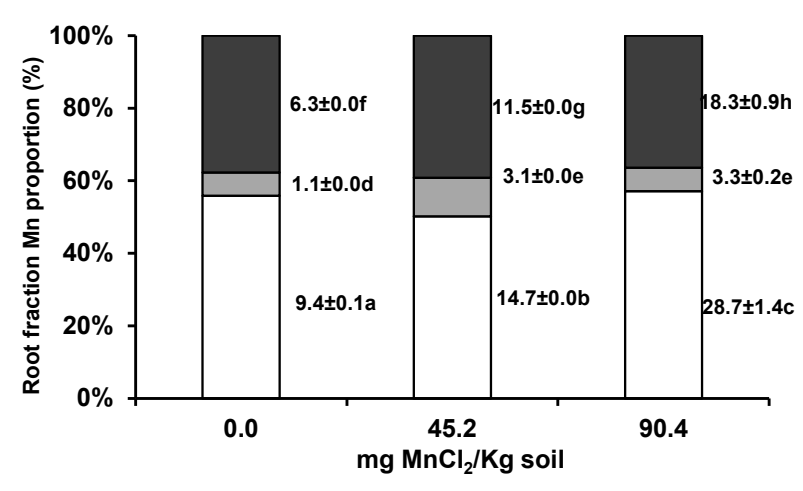

(a)

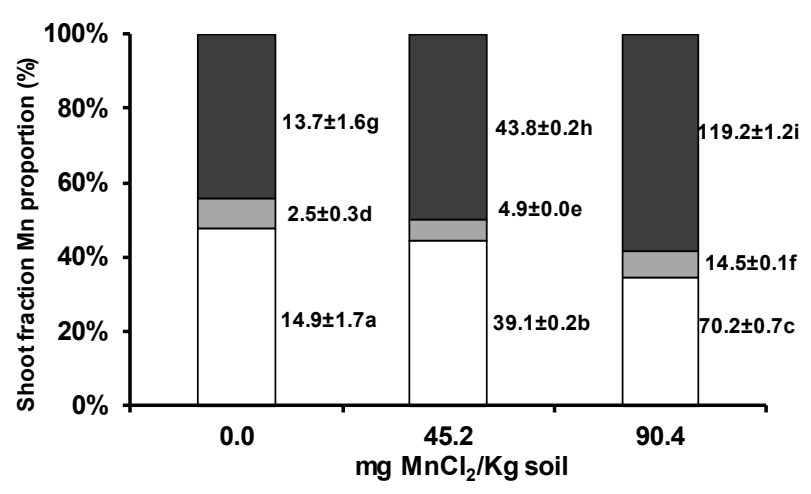

(b)

Figure 2. Subcellular distribution of Mn (cell wall, white columns; organelle, grey columns; and vacuole contents fractions, black columns) in roots (a) and shoots (b) of wheat grown for 3 weeks in an acidic soil supplemented with $\mathrm{MnCl}_{2}$. Values next to bars are fraction element quantities in $100 \mathrm{mg}$ of shoot fresh weight ( $\mu \mathrm{g} / 100 \mathrm{mg}$ FW). Different letters indicate statistically significant differences $(p<0.05)$ on the basis of Tukey's test. 


\subsection{Aluminium}

Aluminium in the soil solution increased with Mn supplementation to the acidic soil (Table 1). Wheat root $\mathrm{Al}$ concentrations were around 10-fold higher than those in shoots. In the control soil ( $0 \mathrm{mg} \mathrm{MnCl}_{2} / \mathrm{kg}$ soil), roots contained $6203 \mathrm{mg} \mathrm{Al} / \mathrm{kg}$ plant DW (dry weight), while in shoots, $\mathrm{Al}$ was detected at $744 \mathrm{mg} / \mathrm{kg}$ DW (Figure 3a). With higher soil Mn levels, $\mathrm{Al}$ concentration decreased at the root system and increased in the shoots. Both whole-plant (BAC) and root (root BCF) Al uptake decreased, while shoot uptake (shoot $\mathrm{BCF}$ ) showed no statistically significant variation (Figure 3b). Aluminium appeared to be rapidly excluded from wheat roots and/or translocated from wheat roots to shoots with increasing soil Mn concentrations, as indicated by the increase in $\mathrm{Al}$ translocation factor (TF) (Figure 3a).

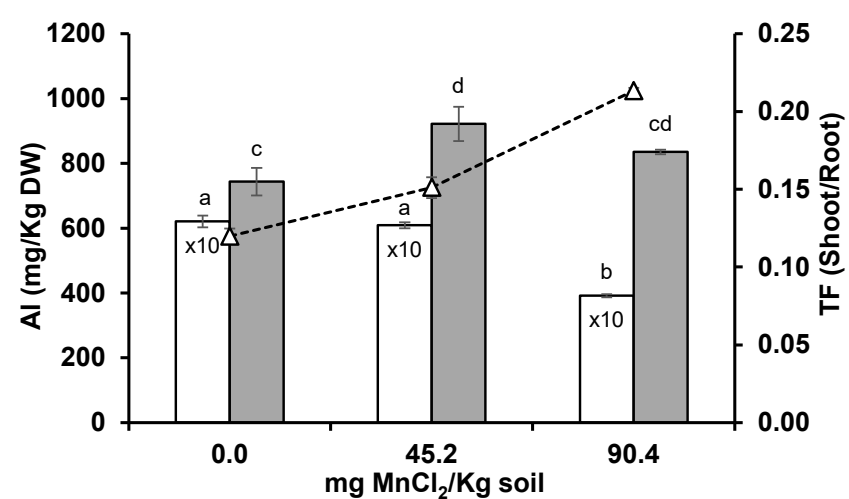

(a)

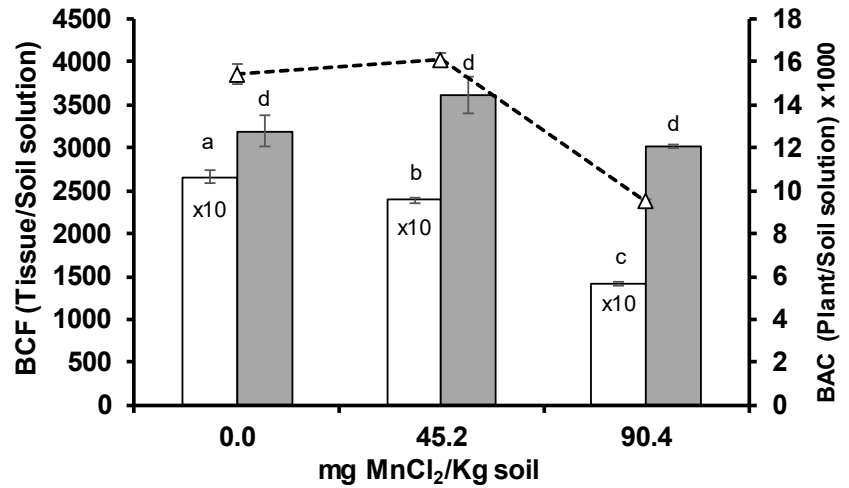

(b)

Figure 3. Concentration ((a), columns), translocation factor (TF, triangles) ((a), line), bioconcentration factors (BCF) ((b), columns), and bioaccumulation coefficient (BAC, triangles) $((\mathbf{b})$, line) of $\mathrm{Al}$ in roots (white columns) and shoots (grey columns) of wheat grown for 3 weeks in an acidic soil supplemented with $\mathrm{MnCl}_{2}$. Different letters indicate statistically significant differences $(p<0.05)$ on the basis of Tukey's test.

In both roots and shoots, $\mathrm{Al}$ was mostly kept at the cell wall fraction and in cellular organelles fraction (Figure $4 \mathrm{a}, \mathrm{b}$ ). In the roots, $\mathrm{Al}$ proportions seemed to increase in the organelle fraction in the intermediate soil Mn level, while in wheat shoots, there was an increase only at the highest supplemented Mn concentration.

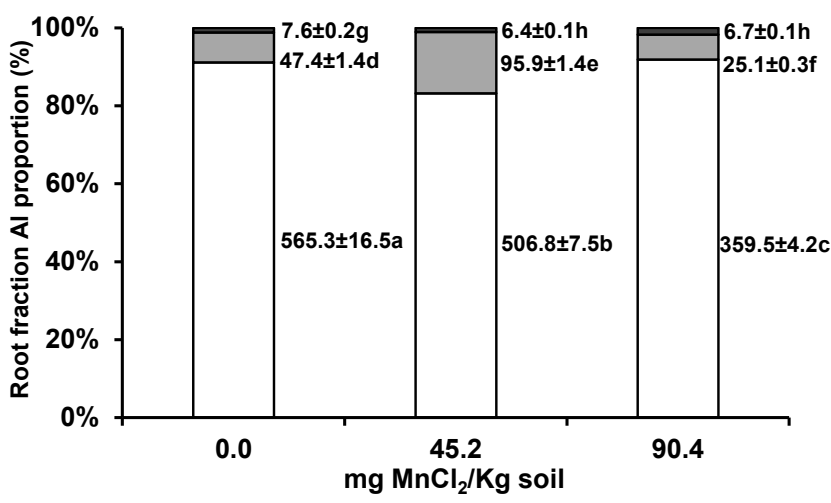

(a)

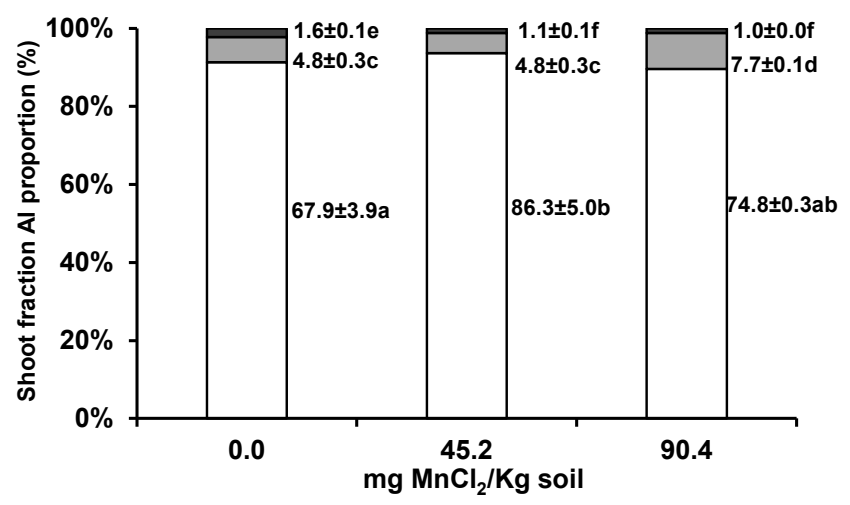

(b)

Figure 4. Subcellular distribution of $\mathrm{Al}$ (cell wall, white columns; organelle, grey columns; and vacuole content fractions, black columns) in roots (a) and shoots (b) of wheat grown for 3 weeks in an acidic soil supplemented with $\mathrm{MnCl}_{2}$. Values next to bars are fraction element quantities in $100 \mathrm{mg}$ of shoot fresh weight ( $\mu \mathrm{g} / 100 \mathrm{mg}$ FW). Different letters indicate statistically significant differences $(p<0.05)$ on the basis of Tukey's test. 


\subsection{Iron}

Soil solution Fe increased with supplemented $\mathrm{Mn}$ in the acidic soil (Table 1). In wheat roots, Fe was detected in concentrations 10-fold higher than in the shoots. While roots decreased from 3260 to $2300 \mathrm{mg} \mathrm{Fe} / \mathrm{kg}$ DW, shoots increased from 400 to $550 \mathrm{mg} \mathrm{Fe} / \mathrm{kg}$ DW (Figure 5a). With higher soil Mn levels, Fe was preferentially translocated from roots to shoots (higher TF values). BCF values were decreased in wheat roots, while in the shoots were increased, with the highest soil Mn concentration, which suggests a preferential Fe uptake to the shoot (Figure $5 b$ ).

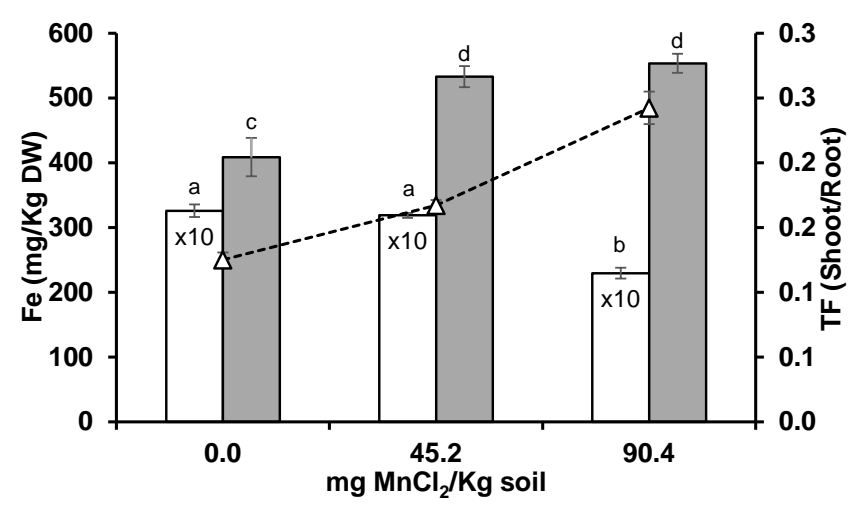

(a)

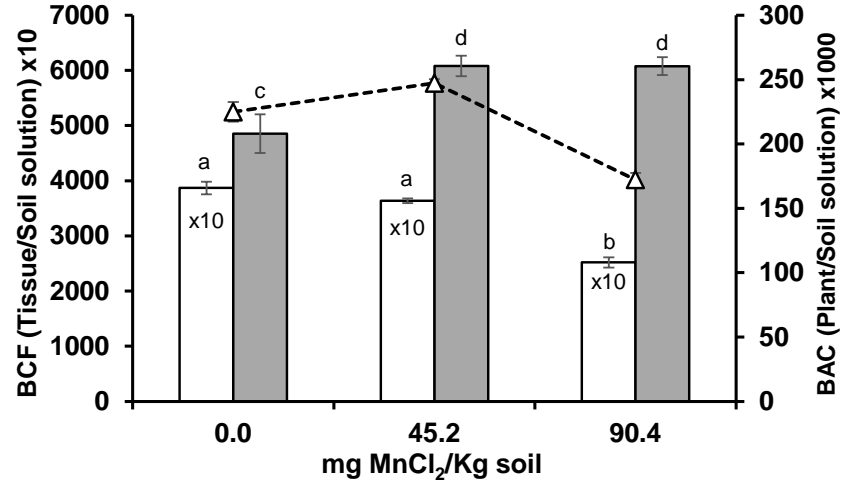

(b)

Figure 5. Concentration $((\mathbf{a})$, columns), translocation factor $(\mathrm{TF}$, triangles) $((\mathbf{a})$, line), bioconcentration factors (BCF) $((\mathbf{b})$, columns), and bioaccumulation coefficient (BAC, triangles) $((\mathbf{b})$, line) of Fe in roots (white columns) and shoots (grey columns) of wheat grown for 3 weeks in an acidic soil supplemented with $\mathrm{MnCl}_{2}$. Different letters indicate statistically significant differences $(p<0.05)$ on the basis of Tukey's test.

Subcellular tissue fractionation allowed for the assessment of preferential Fe acumulation sites. In wheat roots, Fe proportion increased in the apoplast and/or decreased in the cellular organelles (Figure 6a). With increasing soil Mn, there was an intermediate decrease of Fe proportion in the root apoplast. In wheat shoots, at the highest soil Mn concentration, Fe increased its proportion in the cellular organelles (Figure 6b).

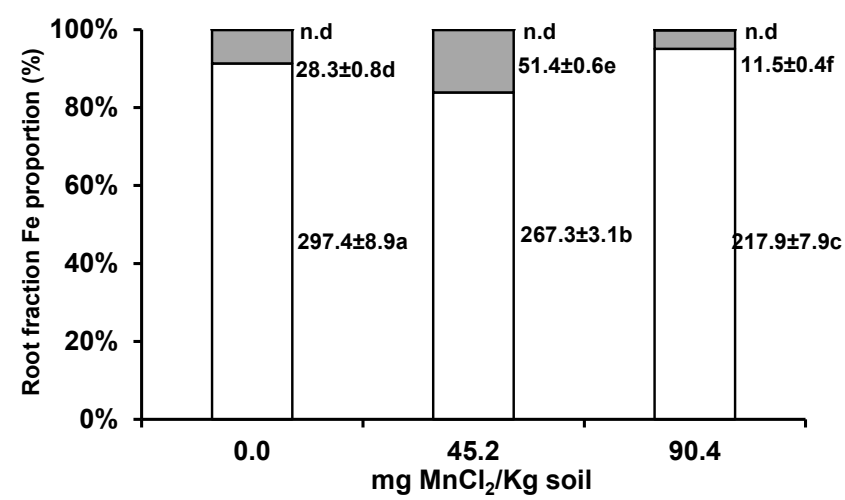

(a)

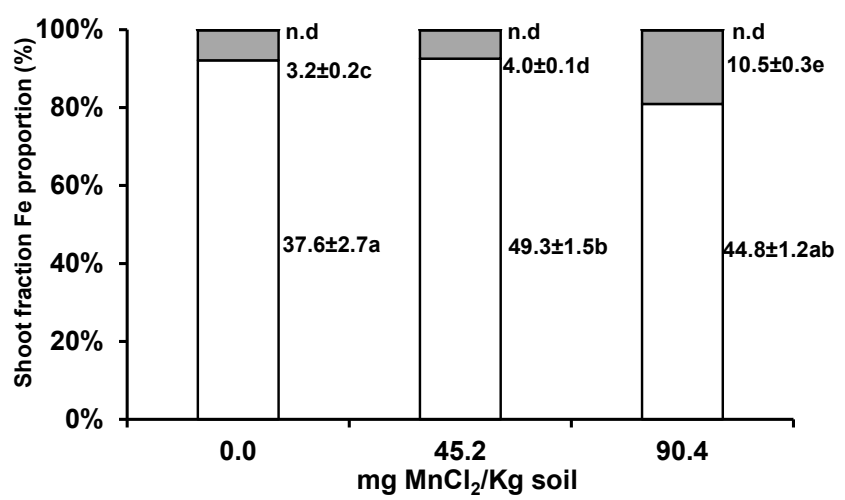

(b)

Figure 6. Subcellular distribution of Fe (cell wall, white columns; organelle, grey columns; and vacuole contents fractions, black columns) in roots (a) and shoots (b) of wheat grown for 3 weeks in an acidic soil supplemented with $\mathrm{MnCl}_{2}$. Values next to bars are fraction element quantities in $100 \mathrm{mg}$ of shoot fresh weight ( $\mu \mathrm{g} / 100 \mathrm{mg} \mathrm{FW})$. Different letters indicate statistically significant differences $(p<0.05)$ on the basis of Tukey's test. 


\subsection{Silicon}

Soil solution Si levels increased with higher bioavailable Mn levels in the acidic soil (Table 1). In wheat roots, Si concentration decreased, while in the shoots increased with higher soil bioavailable Mn concentrations (Figure 7a). Si seemed to be highly translocated to the shoots, indicated by a sharp increase in TF. Root Si BCF showed a decrease, but no statistically significant alteration was detected in the shoots (Figure 7b). Despite the increase in Si concentration at wheat shoots, plant $\mathrm{Si}$ uptake ratio was negatively influenced by increasing soil $\mathrm{Mn}$, as reflected by decreasing BAC, which suggests a high root-toshoot translocation.

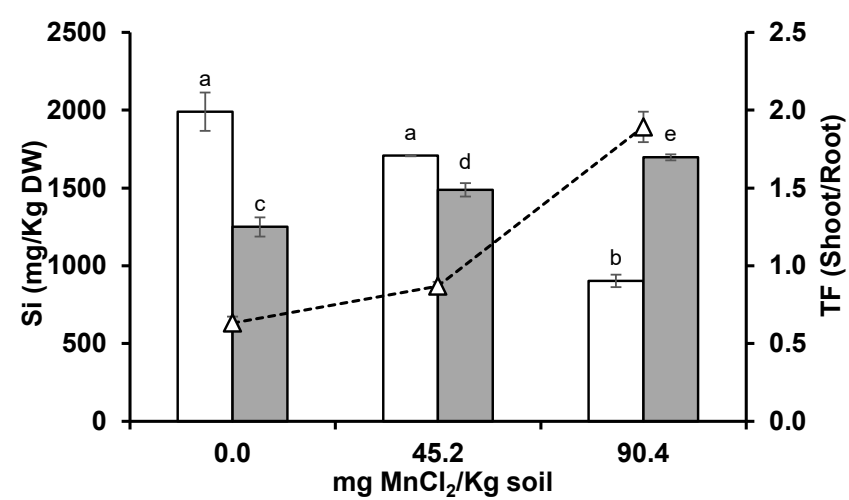

(a)

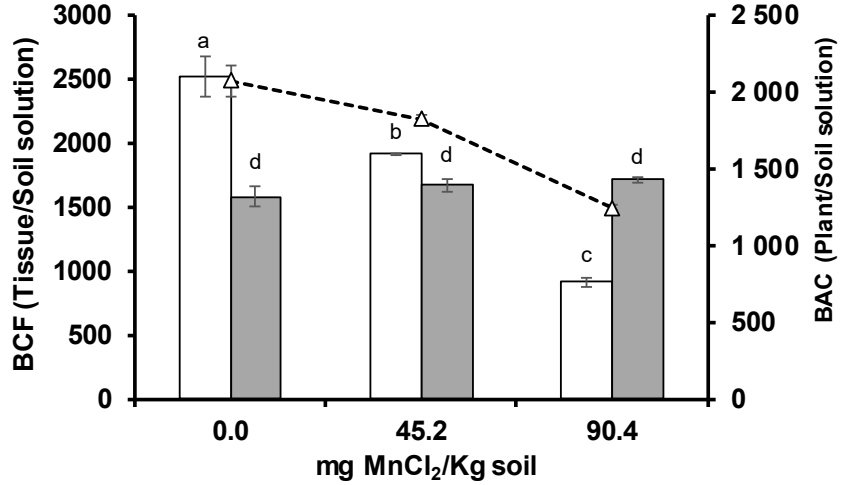

(b)

Figure 7. Concentration ((a), columns), translocation factor (TF, triangles) ((a), line), bioconcentration factors (BCF) $((\mathbf{b})$, columns), and bioaccumulation coefficient (BAC, triangles) $((\mathbf{b})$, line) of $\mathrm{Si}$ in roots (white columns) and shoots (grey columns) of wheat grown for 3 weeks in an acidic soil supplemented with $\mathrm{MnCl}_{2}$. Different letters indicate statistically significant differences $(p<0.05)$ on the basis of Tukey's test.

At the subcellular level, root Si showed a transient decrease in the cell wall fraction with increasing soil bioavailable Mn levels, while in the shoot, Si appeared to increase its proportion in the organelle fraction, with the increase in severity of Mn toxicity (Figure 8a,b).

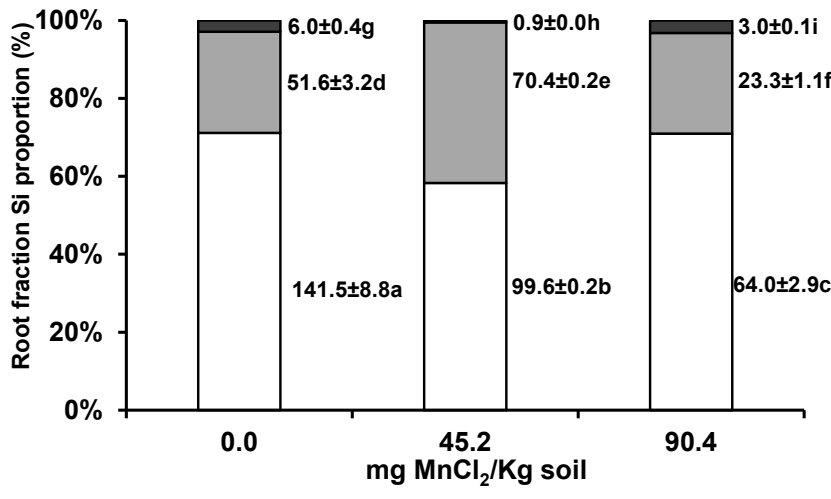

(a)

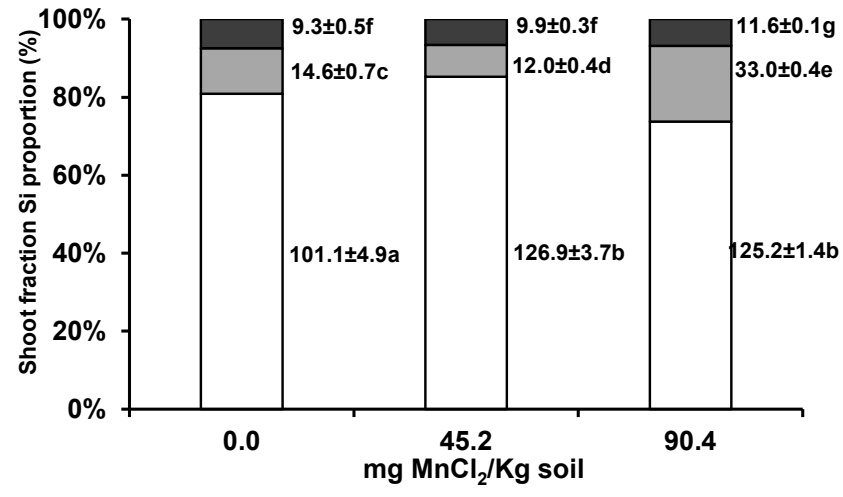

(b)

Figure 8. Subcellular distribution of Si (cell wall, white columns; organelle, grey columns; and vacuole contents fractions, black columns) in roots (a) and shoots (b) of wheat grown for 3 weeks in an acidic soil supplemented with $\mathrm{MnCl}_{2}$. Values next to bars are fraction element quantities in $100 \mathrm{mg}$ of shoot fresh weight ( $\mu \mathrm{g} / 100 \mathrm{mg} \mathrm{FW})$. Different letters indicate statistically significant differences $(p<0.05)$ on the basis of Tukey's test. 


\section{Discussion}

In acidic Cambic soils at southeast Portugal, Mn toxicity has been described as inducing low productivity through reduced plant growth and increased oxidative stress $[28,35]$. In a previous study, wheat nutritional status $(\mathrm{Mg}, \mathrm{Ca}, \mathrm{P}$, and $\mathrm{Mn})$ and antioxidant responses were assessed in an acidic soil with toxic Mn concentrations [28]. In these conditions, higher Mn levels in the soil promoted a decrease in nutrient uptake, a sharp increase in root and shoot Mn concentrations, an increased Mn translocation to shoot tissues, and a preferential accumulation of $\mathrm{Mn}$ at the shoot vacuoles, along with $\mathrm{P}$ and $\mathrm{Mg}$. In the present work, the effects of toxic Mn concentrations in an acidic soil were followed, for the first time, for wheat $\mathrm{Al}, \mathrm{Fe}$, and $\mathrm{Si}$ uptake dynamics and subcellular redistribution. When no $\mathrm{Mn}$ was supplied to the acidic soil, $\mathrm{Mn}, \mathrm{Fe}$, or $\mathrm{Al}$ were detected in wheat shoots at high or toxic levels. In wheat, high concentrations are considered above $2.2 \mathrm{mg} / \mathrm{kg}$ for Al, $100 \mathrm{mg} / \mathrm{kg}$ for $\mathrm{Mn}$, and $100 \mathrm{mg} / \mathrm{kg}$ for Fe [8]. Toxicity caused by individual metals is largely dependent on the concentrations of other metals and nutrients, but also on the susceptibility of wheat genotypes $[3,34,38-40]$. Due to this multi-factorial nature, limits of toxicity for these metals are generally not unanimously recognised in wheat, and several authors report different limits of toxicity [36,41-43].

After soil Mn supplementation, a higher amount of $\mathrm{Mn}$ competed with $\mathrm{Al}, \mathrm{Fe}$, and Si for the negative charges of soil organic matter compounds, which probably led to their increased concentration in the soil solution $[5,43]$. Wheat responded to the elevated bioavailable $\mathrm{Mn}$ concentrations with a reduction in $\mathrm{Al}, \mathrm{Fe}$, and $\mathrm{Si}$ uptake ratios. Root uptake was reduced while shoot concentrations were either slightly increased or unaltered (statistically insignificant changes). These elements seem to be transported outwards through the roots and/or translocated and stored in shoot tissues, along with Mn, to decrease their levels in the root system, in a similar, and apparently nonspecific, mechanism. In wheat, metal exclusion at the root system is a known mechanism to counter Al toxicity. Resistant plants often show an efflux of di- and tricarboxylic organic acids (e.g., citrate, malate, and oxalate) that chelate $\mathrm{Al}$ ions at the rhizosphere or form stable nontoxic complexes at the root surface [44]. The transporters responsible for these mechanisms were also found to permeate other relevant Al chelating anions [45]. Additionally, the release of carboxylates was determined to be a P-mobilising strategy in plants growing in soil with low P levels. This mechanism can be responsible for increased shoot metal levels since carboxylates can mobilise several micronutrients, including $\mathrm{Fe}, \mathrm{Mn}, \mathrm{Cu}$, and $\mathrm{Zn}$, alongside organic and inorganic P [46]. In the present work, similar mechanisms may be promoting increased shoot metal levels and/or element accumulation in the root apoplast, through e.g., metal/organic acid complexes.

In wheat, Fe and Mn uptake and efflux appears to be linked. Increase in Fe levels reduced shoot and root dry weights; promoted Fe accumulation in the shoots; and reduced $\mathrm{Mn}, \mathrm{Ca}$, and $\mathrm{Mg}$ uptake and translocation, despite these responses being dependent on wheat genotype $[47,48]$. Manganese, along with Fe and other metals, share common entry routes at the root system. These elements compete for root uptake through broad specificity metal transporters, whose position and abundance appear to be regulated by the plant to maintain an internal metal homeostasis [49-53].

Under metal toxicity, Si supplementation promotes a great number of stress mitigative mechanisms [54]. Subcellular redistribution of excessive Mn was observed in cucumber and cowpea. In cucumber, shoot $\mathrm{Mn}$ was redirected to the cell wall fraction reducing Mn toxicity stress in the symplast [55], and in cowpea, this mechanism was linked to a modification of cation binding capacity in cell wall components, leading to a co-precipitation of $\mathrm{Mn}$ and Si [56,57]. In wheat, Si seems to enhance root to shoot translocation of Mn [58] and induce changes in the molecular structure of chlorophyll, increasing seedling growth [59]. In the present study, Si accumulated in the organelle fraction in response to increased vacuolar Mn accumulation. This might suggest a protective role under increased stress.

Different soil Mn concentrations seem to promote different stress coping mechanisms at root or shoot tissues. At the root, the intermediate soil Mn concentration promoted an 
increase in organelle proportions of $\mathrm{Al}, \mathrm{Fe}$, and $\mathrm{Si}$, suggesting that, at these toxic Mn levels, stress coping mechanisms involving metal compartmentalisation are mainly occurring in wheat roots. At the highest soil Mn concentration, subcellular redistribution of $\mathrm{Al}, \mathrm{Fe}$, and $\mathrm{Si}$ is mainly observed in wheat shoots. At these Mn levels, wheat plants may be under extreme Mn toxicity and are less efficient in maintaining lower organelle proportions of $\mathrm{Al}$ and Fe. At this stage, increased amounts of $\mathrm{Si}$ in the organelle fraction may be beneficial for coping with metal stress, given its previously described protective effects by managing e.g., wheat shoot photosynthesis, electrolyte leakage, membrane stability, oxidative status, or the accumulation of protective compounds $[23,60]$.

\section{Conclusions}

The occurrence of metal toxicities is common in acidic soils and depends on soil chemical composition and plant characteristics. This phenomenon can generally be allied to induced nutrient deficiencies that complicates pinpointing specific symptoms of toxicity in the plant. In the present work, rising bioavailable Mn levels in the soil led to an overall inhibition in $\mathrm{Al}, \mathrm{Fe}$, and Si uptake. Increase in Mn toxicity stress promoted metal efflux at the root and/or increased metal translocation to the shoot. At the shoot, while Mn seemed to be stored in the vacuole, $\mathrm{Al}, \mathrm{Fe}$, and $\mathrm{Si}$ levels increased in the organelle fraction, suggesting a disruption in element homeostasis. The assessment of element toxicity can take advantage of multi-element fractionation and mass spectrometry-based high-throughput analytical approaches to ascertain the synergistic role of plant essential and non-essential nutrients towards element homeostasis under stress conditions.

Author Contributions: Conceptualisation, J.M.S.F., D.M.T., A.P.P., I.B., P.B. and M.C.; data curation, J.M.S.F. and P.B.; formal analysis, J.M.S.F. and P.B.; funding acquisition, D.M.T., A.P.P., I.B. and M.C.; investigation, J.M.S.F.; methodology, J.M.S.F., D.M.T., A.P.P., I.B., P.B. and M.C.; project administration, M.C.; resources, D.M.T., A.P.P., I.B. and M.C.; writing—original draft, J.M.S.F.; writing-review and editing, J.M.S.F., D.M.T., A.P.P., I.B., P.B. and M.C. All authors have read and agreed to the published version of the manuscript.

Funding: This study was partially funded by Fundo Europeu de Desenvolvimento Regional (FEDER), Programa Operacional Regional Alentejo 2020, under research contract ALT20-03-0145-FEDER-000039.

Institutional Review Board Statement: Not applicable.

Informed Consent Statement: Not applicable.

Data Availability Statement: The raw data supporting the findings of this study are available from the corresponding author (Jorge M. S. Faria) upon reasonable request.

Acknowledgments: The authors wish to thank Filipa Santos, Manuel Figo, and Anabela Cabeça from Évora University staff for the technical support.

Conflicts of Interest: The authors declare no conflict of interest.

\section{References}

1. Kochian, L.V.; Hoekenga, O.A.; Piñeros, M.A. How do crop plants tolerate acid soils? mechanisms of aluminum tolerance and phosphorous efficiency. Annu. Rev. Plant Biol. 2004, 55, 459-493. [CrossRef]

2. Kochian, L.V.; Piñeros, M.A.; Liu, J.; Magalhaes, J.V. Plant Adaptation to Acid Soils: The Molecular Basis for Crop Aluminum Resistance. Annu. Rev. Plant Biol. 2015, 66, 571-598. [CrossRef]

3. George, E.; Horst, W.J.; Neumann, E. Chapter 17-Adaptation of Plants to Adverse Chemical Soil Conditions. In Marschner's Mineral Nutrition of Higher Plants, 3rd ed.; Marschner, P., Ed.; Academic Press: San Diego, CA, USA, 2012; pp. 409-472, ISBN 978-0-12-384905-2.

4. Paterson, E.; Goodman, B.A.; Farmer, V.C. The Chemistry of Aluminium, Iron and Manganese Oxides in Acid Soils. In Soil Acidity; Springer Science and Business Media LLC: Berlin/Heidelberg, Germany, 1991; pp. 97-124.

5. Marschner, H. Mechanisms of adaptation of plants to acid soils. Plant Soil 1991, 134, 1-20. [CrossRef]

6. Mou, D.; Yao, Y.; Yang, Y.; Zhang, Y.; Tian, C.; Achal, V. Plant high tolerance to excess manganese related with root growth, manganese distribution and antioxidative enzyme activity in three grape cultivars. Ecotoxicol. Environ. Saf. 2011, 74, 776-786. [CrossRef] [PubMed] 
7. Goulding, K.W.T. Soil acidification and the importance of liming agricultural soils with particular reference to the United Kingdom. Soil Use Manag. 2016, 32, 390-399. [CrossRef]

8. Khabaz-Saberi, H.; Setter, T.L.; Waters, I. Waterlogging Induces High to Toxic Concentrations of Iron, Aluminum, and Manganese in Wheat Varieties on Acidic Soil. J. Plant Nutr. 2006, 29, 899-911. [CrossRef]

9. Khabaz-Saberi, H.; Barker, S.J.; Rengel, Z. Tolerance to ion toxicities enhances wheat grain yield in acid soils prone to drought and transient waterlogging. Crop. Pasture Sci. 2014, 65, 862-867. [CrossRef]

10. Singh, S.; Tripathi, D.K.; Singh, S.; Sharma, S.; Dubey, N.; Chauhan, D.; Vaculik, M. Toxicity of aluminium on various levels of plant cells and organism: A review. Environ. Exp. Bot. 2017, 137, 177-193. [CrossRef]

11. Zheng, S.J.; Yang, J.L. Target sites of aluminum phytotoxicity. Biol. Plant 2005, 49, 321-331. [CrossRef]

12. Kochian, L.V. Cellular Mechanisms of Aluminum Toxicity and Resistance in Plants. Annu. Rev. Plant Biol. 1995, 46, 237-260. [CrossRef]

13. Schroeder, J.I.; Delhaize, E.; Frommer, W.; Guerinot, M.L.; Harrison, M.J.; Herrera-Estrella, L.; Horie, T.; Kochian, L.; Munns, R.; Nishizawa, N.K.; et al. Using membrane transporters to improve crops for sustainable food production. Nat. Cell Biol. 2013, 497, 60-66. [CrossRef] [PubMed]

14. Sasaki, T.; Yamamoto, Y.; Ezaki, B.; Katsuhara, M.; Ahn, S.J.; Ryan, P.R.; Delhaize, E.; Matsumoto, H. A wheat gene encoding an aluminum-activated malate transporter. Plant J. 2004, 37, 645-653. [CrossRef] [PubMed]

15. Becker, M.; Asch, F. Iron toxicity in rice-Conditions and management concepts. J. Plant Nutr. Soil Sci. 2005, 168, 558-573. [CrossRef]

16. Camargo, C.E.D.O.; Felicio, J.C.; Filho, A.W.P.F.; De Freitas, J.G.; Ramos, V.J.; Kanthack, R.A.D.; De Castro, J.L. Melhoramento do trigo: XXX. Avaliação de linhagens com tolerância a toxicidade de alumínio, manganês e ferro em condições de campo. Bragantia 1995, 54, 81-93. [CrossRef]

17. Camargo, C.E.D.O.; Felício, J.C.; De Freitas, J.G.; Filho, A.W.P.F. Tolerância de trigo, triticale e centeio a diferentes níveis de ferro em solução nutritiva. Bragantia 1988, 47, 295-304. [CrossRef]

18. Keisling, T.C.; Thompson, L.F.; Slabaugh, W.R. Visual symptoms and tissue manganese concentrations associated with manganese toxicity in wheat. Commun. Soil Sci. Plant Anal. 1984, 15, 537-540. [CrossRef]

19. Fernando, D.R.; Lynch, J.P. Manganese phytotoxicity: New light on an old problem. Ann. Bot. 2015, 116, 313-319. [CrossRef] [PubMed]

20. Huang, H.; Zhao, Y.; Xu, Z.; Zhang, W.; Jiang, K. Physiological responses of Broussonetia papyrifera to manganese stress, a candidate plant for phytoremediation. Ecotoxicol. Environ. Saf. 2019, 181, 18-25. [CrossRef]

21. Sparrow, L.; Uren, N. The role of manganese toxicity in crop yellowing on seasonally waterlogged and strongly acidic soils in north-eastern Victoria. Aust. J. Exp. Agric. 1987, 27, 303-307. [CrossRef]

22. El-Jaoual, T.; Cox, D.A. Manganese toxicity in plants. J. Plant Nutr. 1998, 21, 353-386. [CrossRef]

23. Doncheva, S.; Poschenrieder, C.; Stoyanova, Z.; Georgieva, K.; Velichkova, M.; Barceló, J. Silicon amelioration of manganese toxicity in Mn-sensitive and Mn-tolerant maize varieties. Environ. Exp. Bot. 2009, 65, 189-197. [CrossRef]

24. de Vargas, J.P.; dos Santos, D.R.; Bastos, M.C.; Schaefer, G.; Parisi, P.B. Application forms and types of soil acidity corrective: Changes in depth chemical attributes in long term period experiment. Soil Tillage Res. 2019, 185, 47-60. [CrossRef]

25. De Jesus, L.R.; Batista, B.L.; Lobato, A.K.D.S. Silicon reduces aluminum accumulation and mitigates toxic effects in cowpea plants. Acta Physiol. Plant. 2017, 39, 138. [CrossRef]

26. Millaleo, R.; Diaz, M.R.-; Ivanov, A.G.; Mora, M.L.; Alberdi, M. Manganese as essential and toxic element for plants: Transport, accumulation and resistance mechanisms. J. Soil Sci. Plant Nutr. 2010, 10, 470-481. [CrossRef]

27. Che, J.; Yamaji, N.; Shao, J.F.; Ma, J.F.; Shen, R.F. Silicon decreases both uptake and root-to-shoot translocation of manganese in rice. J. Exp. Bot. 2016, 67, 1535-1544. [CrossRef] [PubMed]

28. Faria, J.M.; Teixeira, D.M.; Pinto, A.P.; Brito, I.; Barrulas, P.; Alho, L.; Carvalho, M. Toxic levels of manganese in an acidic Cambisol alters antioxidant enzymes activity, element uptake and subcellular distribution in Triticum aestivum. Ecotoxicol. Environ. Saf. 2020, 193, 110355. [CrossRef]

29. Faria, J.; Teixeira, D.; Pinto, A.; Brito, I.; Barrulas, P.; Carvalho, M. The Protective Biochemical Properties of Arbuscular Mycorrhiza Extraradical Mycelium in Acidic Soils Are Maintained throughout the Mediterranean Summer Conditions. Agronomy 2021, 11, 748. [CrossRef]

30. Faria, J.; Teixeira, D.; Pinto, A.P.; Brito, I.; Barrulas, P.; Carvalho, M. Arbuscular Mycorrhiza Inoculum Type Influences Phosphorus Subcellular Distribution in Shoots of Wheat Grown in Acidic Soil under Sustainble Agricultural Practices. In Proceedings of the 1st International Electronic Conference on Plant Science, Basel, Switzerland, 1-15 December 2020; p. 8596.

31. Faria, J.M.S.; Pinto, A.P.; Teixeira, D.; Brito, I.; Carvalho, M. Diversity of Native Arbuscular Mycorrhiza Extraradical Mycelium Influences Antioxidant Enzyme Activity in Wheat Grown Under Mn Toxicity. Bull. Environ. Contam. Toxicol. 2021, 1-6. [CrossRef]

32. Goss, M.J.; Carvalho, M.J.G.P.R. Manganese toxicity: The significance of magnesium for the sensitivity of wheat plants. Plant Soil 1992, 139, 91-98. [CrossRef]

33. Goss, M.J.; Carvalho, M.J.G.P.R.; Cosimini, V.; Fearnhead, M.L. An approach to the identification of potentially toxic concentrations of manganese in soils. Soil Use Manag. 1992, 8, 40-43. [CrossRef] 
34. Le Bot, J.; Goss, M.; Carvalho, M.J.G.P.R.; Van Beusichem, M.L.; Kirkby, E.A. The significance of the magnesium to manganese ratio in plant tissues for growth and alleviation of manganese toxicity in tomato (Lycopersicon esculentum) and wheat (Triticum aestivum) plants. Plant Soil 1990, 124, 205-210. [CrossRef]

35. Carvalho, M.; Goss, M.J.; Teixeira, D.M. Manganese toxicity in Portuguese Cambisols derived from granitic rocks: Causes, limitations of soil analyses and possible solutions. Rev. Cienc. Agrar. 2015, 38, 518-527. [CrossRef]

36. Brito, I.; Carvalho, M.; Alho, L.; Goss, M. Managing arbuscular mycorrhizal fungi for bioprotection: Mn toxicity. Soil Biol. Biochem. 2014, 68, 78-84. [CrossRef]

37. Zhang, H.; Guo, Q.; Yang, J.; Shen, J.; Chen, T.; Zhu, G.; Chen, H.; Shao, C. Subcellular cadmium distribution and antioxidant enzymatic activities in the leaves of two castor (Ricinus communis L.) cultivars exhibit differences in Cd accumulation. Ecotoxicol. Environ. Saf. 2015, 120, 184-192. [CrossRef]

38. Khabaz-Saberi, H.; Rengel, Z. Aluminum, manganese, and iron tolerance improves performance of wheat genotypes in waterlogged acidic soils. J. Plant Nutr. Soil Sci. 2010, 173, 461-468. [CrossRef]

39. Setter, T.; Waters, I.; Sharma, S.K.; Singh, K.N.; Kulshreshtha, N.; Yaduvanshi, N.P.S.; Ram, P.C.; Rane, J.; McDonald, G.; KhabazSaberi, H.; et al. Review of wheat improvement for waterlogging tolerance in Australia and India: The importance of anaerobiosis and element toxicities associated with different soils. Ann. Bot. 2008, 103, 221-235. [CrossRef]

40. Wheeler, D.M.; Power, I.L. Comparison of plant uptake and plant toxicity of various ions in wheat. Plant Soil 1995, 172, 167-173. [CrossRef]

41. Darkó, É.; Ambrus, H.; Stefanovits-Bányai, É.; Fodor, J.; Bakos, F.; Barnabás, B. Aluminium toxicity, Al tolerance and oxidative stress in an Al-sensitive wheat genotype and in Al-tolerant lines developed by in vitro microspore selection. Plant Sci. 2004, 166, 583-591. [CrossRef]

42. Broadley, M.; Brown, P.; Cakmak, I.; Rengel, Z.; Zhao, F. Function of Nutrients: Micronutrients. Marschner's Miner. Nutr. High. Plants 2012, 191-248. [CrossRef]

43. Pinto, E.; Aguiar, A.; Ferreira, I. Influence of Soil Chemistry and Plant Physiology in the Phytoremediation of Cu, Mn, and Zn. Crit. Rev. Plant Sci. 2014, 33, 351-373. [CrossRef]

44. Delhaize, E.; Gruber, B.; Ryan, P.R. The roles of organic anion permeases in aluminium resistance and mineral nutrition. FEBS Lett. 2007, 581, 2255-2262. [CrossRef]

45. Pineros, M.; Cançado, G.M.; Kochian, L. Novel Properties of the Wheat Aluminum Tolerance Organic Acid Transporter (TaALMT1) Revealed by Electrophysiological Characterization in Xenopus Oocytes: Functional and Structural Implications. Plant Physiol. 2008, 147, 2131-2146. [CrossRef]

46. Lambers, H.; Hayes, P.; Laliberté, E.; Oliveira, R.; Turner, B. Leaf manganese accumulation and phosphorus-acquisition efficiency. Trends Plant Sci. 2015, 20, 83-90. [CrossRef]

47. Ghasemi-Fasaei, R.; Ronaghi, A. Interaction of Iron with Copper, Zinc, and Manganese in Wheat as Affected by Iron and Manganese in a Calcareous Soil. J. Plant Nutr. 2008, 31, 839-848. [CrossRef]

48. Khabaz-Saberi, H.; Rengel, Z.; Wilson, R.; Setter, T.L. Variation for tolerance to high concentration of ferrous iron $\left(\mathrm{Fe}^{2+}\right)$ in Australian hexaploid wheat. Euphytica 2009, 172, 275-283. [CrossRef]

49. Castaings, L.; Caquot, A.; Loubet, S.; Curie, C. The high-affinity metal Transporters NRAMP1 and IRT1 Team up to Take up Iron under Sufficient Metal Provision. Sci. Rep. 2016, 6, 37222. [CrossRef] [PubMed]

50. Ishimaru, Y.; Bashir, K.; Nakanishi, H.; Nishizawa, N.K. OsNRAMP5, a major player for constitutive iron and manganese uptake in rice. Plant Signal. Behav. 2012, 7, 763-766. [CrossRef]

51. Ishimaru, Y.; Masuda, H.; Bashir, K.; Inoue, H.; Tsukamoto, T.; Takahashi, M.; Nakanishi, H.; Aoki, N.; Hirose, T.; Ohsugi, R.; et al. Rice metal-nicotianamine transporter, OsYSL2, is required for the long-distance transport of iron and manganese. Plant J. 2010, 62, 379-390. [CrossRef] [PubMed]

52. Barberon, M.; Dubeaux, G.; Kolb, C.; Isono, E.; Zelazny, E.; Vert, G. Polarization of IRON-REGULATED TRANSPORTER 1 (IRT1) to the plant-soil interface plays crucial role in metal homeostasis. Proc. Natl. Acad. Sci. USA 2014, 111, 8293-8298. [CrossRef]

53. Cointry, V.; Vert, G. The bifunctional transporter-receptor IRT 1 at the heart of metal sensing and signalling. New Phytol. 2019, 223, 1173-1178. [CrossRef]

54. Bhat, J.A.; Shivaraj, S.M.; Singh, P.; Navadagi, D.B.; Tripathi, D.K.; Dash, P.K.; Solanke, A.U.; Sonah, H.; Deshmukh, R. Role of Silicon in Mitigation of Heavy Metal Stresses in Crop Plants. Plants 2019, 8, 71. [CrossRef] [PubMed]

55. Rogalla, H.; Römheld, V. Role of leaf apoplast in silicon-mediated manganese tolerance of Cucumis sativus L. Plant Cell Environ. 2002, 25, 549-555. [CrossRef]

56. Horst, W.J.; Fecht, M.; Naumann, A.; Wissemeier, A.H.; Maier, P. Physiology of manganese toxicity and tolerance in Vigna unguiculata (L.) Walp. J. Plant Nutr. Soil Sci. 1999, 162, 263-274. [CrossRef]

57. Iwasaki, K.; Maier, P.; Fecht, M.; Horst, W.J. Leaf apoplastic silicon enhances manganese tolerance of cowpea (Vigna unguiculata). J. Plant Physiol. 2002, 159, 167-173. [CrossRef]

58. Greger, M.; Landberg, T.; Vaculík, M. Silicon Influences Soil Availability and Accumulation of Mineral Nutrients in Various Plant Species. Plants 2018, 7, 41. [CrossRef] 
59. Sun, D.; Hussain, H.I.; Yi, Z.; Rookes, J.E.; Kong, L.; Cahill, D.M. Mesoporous silica nanoparticles enhance seedling growth and photosynthesis in wheat and lupin. Chemosphere 2016, 152, 81-91. [CrossRef]

60. Alzahrani, Y.; Kuşvuran, A.; Alharby, H.F.; Kuşvuran, S.; Rady, M.M. The defensive role of silicon in wheat against stress conditions induced by drought, salinity or cadmium. Ecotoxicol. Environ. Saf. 2018, 154, 187-196. [CrossRef] 